\title{
A Study on Impact in Exchange Rate of Indian Rupee versus US Dollar with Special Reference to Indian Capital Market
}

\author{
Ms. M. Indumathi ${ }^{1}$, Dr. N. Pagutharivu ${ }^{2}$ \\ ${ }^{1}$ Research Scholar, Department of Management, Hindusthan college of Arts and Science, Coimbatore, India \\ ${ }^{2}$ Assistant Professor, Department of Management, Hindusthan college of Arts and Science, Coimbatore, India
}

\begin{abstract}
Foreign Exchange Rate is the largest financial market function is converting any foreign currency into another currency. A market based exchange rate will change whenever the values of either of the two component currencies change. A currency will tend to become more valuable whenever demand for it is greater than the available supply. Increased demand for a currency is due to either an increased transaction demand for money, or increased speculative demand for money. The transaction demand for money is highly correlated to the countries level of business activity, Gross Domestic Product (GDP), and employment levels. Most of the peoples are unemployed, the less the public as a whole will spend on goods and services. Central banks typically have little difficulty in adjusting the available money supply to accommodate changes in the demand for money due to business transactions. Such fluctuations in exchange rate have its impact on the economic growth of the economy. Hence the present study aims at finding out the Impact in the exchange rate and stock market.
\end{abstract}

Keywords-Capital Market, NSE, GDP, Volatility.

\section{INTRODUCTION}

FOREX (Foreign Exchange market), refers to an international exchange market where currencies are bought and sold. The Foreign Exchange Market began in the 1970's, when free exchange rates and floating currencies were introduced. In such an environment only participants in the market determine the price of one currency against another, based upon supply and demand for that currency.

The foreign exchange market is most often called the forex market, or simply the $F X$ market is the most traded financial market in the world. The forex market is the crossroads for international capital, the intersection through which global commercial and investment flows have to move. International trade flows, such as when a Swiss electronics company purchases Japanese-made components, were the original basis for the development of the forex markets. Today, however, global financial and investment flows dominate trade as the primary nonspeculative source of forex market volume. Whether it's an Australian pension fund investing in U.S. Treasury bonds, or a British insurer allocating assets to the Japanese equity market, or a German conglomerate purchasing a Canadian manufacturing facility, each crossborder transaction passes through the forex market at some stage.

More than anything else, the forex market is a trader's market. It's a market that's open around the clock six days a week, enabling traders to act on news and events as they happen. It's a market where half-billion-dollar trades can be executed in a matter of seconds and may not even move prices noticeably. Forex is a somewhat unique market for a number of reasons. Firstly, it is one of the few markets in which it can be said with very few qualifications that it is free of external controls and that it cannot be manipulated. It is also the largest liquid financial market, with trade reaching between 1 and 1.5 trillion US dollars a day. With this much money moving this fast, it is clear why a single investor would find it near impossible to significantly affect the price of a major currency. Furthermore, the liquidity of the market means that unlike some rarely traded stock, traders are able to open and close positions within a few seconds as there are always willing buying and selling.

Another somewhat unique characteristic of the FOREX money market is the variance of its participants. Investors find a number of reasons for entering the market, some as longer term hedge investors, while others utilize massive credit lines to seek large short term gains. Interestingly, unlike blue-chip stocks, which are usually most attractive only to the long term investor, the combination of rather constant but small daily fluctuations in currency prices, create an environment which attracts investors with a broad range of strategies. 


\section{FLUCTUATIONS IN EXCHANGE RATE}

A market based exchange rate will change whenever the values of either of the two component currencies change. A currency will tend to become more valuable whenever demand is greater than the available supply. It will become less valuable whenever demand is less than available supply (this does not mean people no longer want money, it just means they prefer holding their wealth in some other form, possibly in another currency).

Increased demand for a currency is due to either an increased transaction demand for money, or an increased speculative demand for money. The transaction demand for money is highly correlated to the country's level of business activity, Gross Domestic Product (GDP), and employment levels. The more the people are unemployed, the less the public as a whole will spend on goods and services. Central banks typically have little difficulty in adjusting the available money supply to accommodate changes in the demand for money due to business transactions.

\section{VOLATILITY}

Volatility refers to the amount of uncertainty or risk about the size of change in a security's value. A higher volatility means that a security's value can potentially be spread out over a larger range of values. This means that the price of the security can change dramatically over a short time period in either direction. A lower volatility means that security's value does not fluctuate dramatically, but changes in value at a steady pace over period of time.

One measure of the relative volatility of a particular stock to the market is beta. A beta approximates the overall volatility of a security's returns against the returns of a relevant benchmark (usually the S\&P 500 is used). For example, a stock with a beta value of 1.1 has historically moved $110 \%$ for every $100 \%$ move in the benchmark, based on price level. Conversely, a stock with a beta of 9 has historically moved $90 \%$ for every $100 \%$ move in the underlying index.

Volatility refers to the frequency and severity with which the market price of an investment fluctuates. Certain psychological studies have shown that investors as a whole are happiest when volatility is lowest, even if that means making less money over time. It is possible to make money from volatility. Value investors seek to buy assets when no one else wants them. Certain types of option traders make much higher profits when fear is rampant because people are willing to pay those more to write derivatives such as put options. In fact, it may be fair to say that the more professional and intelligent investors, the more beneficial volatility is to him because he can use it to buy more of what is cheap and sell more of what is expensive.
For long-term investors regularly putting away money through a dollar cost averaging plan, volatility is meaningless. The regular contributions should, over the course of many years, even out the average price paid and mean nothing more than a footnote in the history of your financial life.

\section{NATIONAL STOCK EXCHANGE (NSE)}

In the fast growing Indian financial market, there are 24 stock Exchanges are trading securities. The National Stock Exchange of India (NSE) situated in Mumbai - is the largest and most advanced exchange with 1016 companies listed and 726 trading members. The NSE is owned by the group of leading financial institutions such as Indian Bank or Life Insurance Corporation of India. However, in the totally de-metalized Exchange, the ownership as well as the management does not have a right to trade on the Exchange. Only qualified traders can be involved in the securities trading.

The National Stock Exchange of India Ltd. provides its clients with a single, fully electronic trading platform that is operated through a VSAT network. Unlike most world Exchanges, the NSE uses the satellite communication system that connects traders from 345 Indian cities. The advanced technologies enable up to 6 million trades to be operated daily on the NSE trading platform.

\section{HISTORY OF NSE OF INDIA}

Capital market reforms in India and the launch of the Securities and Exchange Board of India (SEBI) accelerated the incorporation of the second Indian stock exchange called the National Stock Exchange (NSE) in 1992. After a few years of operations, the NSE has become the largest stock exchange in India.

Three segments of the NSE trading platform were established one after another. The Wholesale Debt Market (WDM) commenced operations in June 1994 and the Capital Market (CM) segment was opened at the end of 1994. Finally, the Futures and Options segment began operating in 2000. Today the NSE takes the 14th position in the top 40 futures Exchanges in the world. In 1996, the National Stock Exchange of India launched S\&P CNX Nifty and CNX Junior Indices that make up 100 most liquid stocks in India. CNX Nifty is a diversified index of 50 stocks from 25 different economy sectors. The Indices are owned and managed by India Index Services and Products Ltd (IISL) that has a consulting and licensing agreement with Standard \& Poor's.

In 1998, the National Stock Exchange of India launched its web-site and was the first exchange in India that started trading stock on the Internet in 2000. The NSE has also proved its leadership in the Indian financial market by gaining many awards such as 'Best IT Usage Award' 
by Computer Society in India (in 1996 and 1997) and CHIP Web Award by CHIP magazine (1999).

\section{INDICES UNDER NSE}

The following table shows the major and other indices under National Stock Exchange (NSE) in India.

\section{LIST OF INDICES UNDER NSE}

\begin{tabular}{|c|c|}
\hline 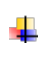 & S\&P CNX NIFTY \\
\hline & S\&P CNX NIFTY JUNIOR \\
\hline \# & S\&P CNX IT \\
\hline 4 & S\&P CNX BANK \\
\hline$\$$ & S\&P CNX 100 \\
\hline 4 & S\&P CNX DEFTY \\
\hline \$ & S\&P CNX 500 \\
\hline 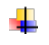 & S\&P CNX MIDCAP \\
\hline$\$$ & S\&P CNX INFRASTUCTURE \\
\hline \# & S\&P CNX 200 \\
\hline + & S\&P CNX MIDCAP 50 \\
\hline$\$$ & S\&P CNX SMALL CAP INDEX \\
\hline 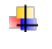 & S\&P CNX MIDCAP 200 \\
\hline 4 & S\&P CNX AUTO \\
\hline 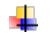 & S\&P CNX COMMODITIES \\
\hline 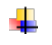 & S\&P CNX CONSUMPTION \\
\hline 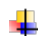 & S\&P CNX MEDIA \\
\hline 1 & S\&P CNX MEDIA \\
\hline+ & S\&P CNX METALS \\
\hline 4 & S\&P CNX MNC \\
\hline \# & S\&P CNX DIVIDEND OPPORTUNITIES \\
\hline 1 & S\&P CNX ENERGY \\
\hline 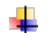 & S\&P CNX FINANCE \\
\hline & S\&P CNX FMCG \\
\hline & S\&P CNX PARMA \\
\hline
\end{tabular}

There are totally 9 major indices and 14 other indices in NSE. The sample indices taken for this study were eight major indices and one other index.

\section{STATEMENT OF THE PROBLEM}

Foreign Exchange Rate is the largest financial market function is converting any foreign currency into another currency. A market based exchange rate will change whenever the values of either of the two component currencies change. A currency will tend to become more valuable whenever demand for it is greater than the available supply. Increased demand for a currency is due to either an increased transaction demand for money, or increased speculative demand for money. The transaction demand for money is highly correlated to the countries level of business activity, Gross Domestic Product (GDP), and employment levels. Most of the peoples are unemployed, the less the public as a whole will spend on goods and services. Central banks typically have little difficulty in adjusting the available money supply to accommodate changes in the demand for money due to business transactions. Such fluctuations in exchange rate have its impact on the economic growth of the economy. Hence the present study aims at finding out the Impact in the exchange rate and stock market.

\section{NEED OF THE STUDY}

Various studies have been made to test the Impact of National Stock Exchange indices in India and US exchange rate. In Indian concept, many researchers have been carried out to examine the volatility of various commodities, stocks and index future. No comprehensive study has been undertaken to test the Impact and effects of Exchange rate in Indian Stock Exchange indices. Hence, the present study made an attempt to test the Impact and effects of Exchange rate in National Stock Exchange indices with help of ADF.

OBJECTIVE OF THE STUDY

- To analyze the impact of movements with special reference to ADF tests

\section{SAMPLE SELECTION}

In NSE S\&P CNX Nifty, CNX Nifty Junior, CNX 100, CNX Bank, CNX Infrastructure, CNX 200,S\&P CNX 500, CNX IT, CNX Midcap, Nifty Midcap 50, CNX Small cap Index, S\&P CNX Defty, CNX Midcap 200, CNX Auto, CNX Commodities, CNX Consumption, CNX Media, CNX Metals, CNX MNC, CNX Dividend Opportunities, CNX Energy, CNX Finance, CNX FMCG, CNX Parma Indices are available. Here I have taken major nine indices because most traded indices in National Stock Exchange.

List of Selected National Stock Index Indices

\begin{tabular}{|c|l|}
\hline S.NO & Name of the indices \\
\hline 1 & S\&P CNX INFRASTRUCTURE \\
\hline 2 & S\&P CNX IT \\
\hline 3 & S\&P CNX MIDCAP \\
\hline 4 & S\&P CNX 500 \\
\hline 5 & S\&P CNX BANK INDEX \\
\hline 6 & S\&P CNX NIFTY JOUNIOR \\
\hline 7 & S\&P CNX DEFTY \\
\hline 8 & S\&P CNX100 \\
\hline 9 & S\&P CNXNIFTY \\
\hline
\end{tabular}

\section{SOURCE OF DATA}

Secondary data is the information that is already available and which is used by the researcher as source for data used in his/her research. Different forms of secondary data include:

- Journals;

- Books;

- Census Data;

- Newspaper articles; and

- Biographies 
The data for the present study is mainly collected form Secondary data for stock exchange web sites:

www.yahoofinance.com
www.bloomberg.com
www.rbi.org.in
www.google.com

Further, the additional information were collected from the journals, books, published reports etc. the references of all those material referred were listed in Bibliography section.

\section{PERIOD OF THE STUDY}

The present study covers five year period from Jan 2009 to Dec 2013. The daily closing sector price indices, exchange rates are used for the period 1 Jan 2009 to 31 Dec 2013. The foreign exchanges are stated in US dollars per local currency. These variables are used to demonstrate the impact of exchange and interest rate changes on the underlying index volatility. Composite index, such as S\&P CNX Infrastructure, S\&P CNX IT, S\&P CNX MIDCAP, S\&P CNX 500, S\&P CNX Bank index, S\&P CNX NIFTY JOUNIOR, S\&P CNX DEFTY, S\&P CNX100, S\&P CNXNIFTY are used for analysis .The National Stock Exchange indices are especially important to examine because they are widely used for measuring sector performance in US and financial market.

\section{TOOLS USED FOR ANALYSIS}

\section{Augmented Dickey-Fuller Test}

In statistics and econometrics, an augmented DickeyFuller test (ADF) is a test for a unit root in a time series sample. It is an augmented version of the Dickey-Fuller trest for a larger and more complicated set of time series models. The augmented Dickey-Fuller (ADF) statistic, used in the test, is a negative number. The more negative it is, the stronger the rejection of the hypothesis that there is a unit roots at some level of confidence.

In statistics and econometrics, an augmented DickeyFuller test (ADF) is a test for a unit root in a time series samrple. It is an augmented version of the Dickey-Fuller test for a larger and more complicated set of time series models. The augmented Dickey-Fuller (ADF) statistic, used in the test, is a negative number. The more negative it is, the stronger the rejection of the hypothesis that there is a unit roots at some level of confidence.

A unit root test tests whether a time series variable is nonstationary using an autoregressive model. The most famous test is the Augmented Dickey-Fuller test. Another test is the Phillips-Perron test. Both these tests use the existence of a unit root as the null hypothesis.

Definition: An augmented Dickey-Fuller test is a test for a unit root in a time series sample. An augmented DickeyFuller test is a version of the Dickey-Fuller test for a larger and more complicated set of time series models.
The augmented Dickey-Fuller (ADF) statistic, used in the test, is a negative number. The more negative it is, the stronger the rejection of the hypothesis that there is a unit root at some level of confidence. Dickey-Fuller unit-root tests are conducted through the ordinary least squares (OLS) estimation of regression models incorporating either an intercept or a linear trend. Consider the autoregressive AR model

$x_{t}=\rho x_{t-1}+\varepsilon_{t}, t=1,2, \ldots, N$,

Where,

$x_{0}=0 ;|\rho| \leq 1$ and $\varepsilon_{t}$ is a real valued sequence of independent random variables with mean zero and variance $\sigma^{2}$. If $\rho=1$, the process $\left\{x_{t}\right\}$ is nonstationary and it is known as a random walk process. In contrast, if $|\rho|<$ 1 , the process $\left\{x_{t}\right\}$ is stationary. The maximum likelihood estimator of $\rho$ is the OLS estimator

$$
\hat{\rho}=\left(\sum_{t=2}^{N} x_{t-1}^{2}\right)^{-1} \sum_{t=2}^{N} x_{t} x_{t-1}
$$

Under the null hypothesis that $\rho=1$, Dickey and Fuller (1979) showed that $\hat{\rho}$ is characterized by

$$
N(\hat{\rho}-1)=\frac{N \sum_{t=2}^{N}\left(x_{t} x_{t-1}-x_{t-1}^{2}\right)}{\sum_{t=2}^{N} x_{t-1}^{2}} \stackrel{D}{\longrightarrow} \frac{\Lambda^{2}-1}{2 \Gamma}
$$

Where,

$$
\begin{aligned}
& (\Gamma, \Lambda)=\left(\sum_{i=1}^{\infty} \gamma_{i}^{2} Z_{i}^{2}, \sum_{i=1}^{\infty} 2^{1 / 2} \gamma_{i} Z_{i}\right) \\
& \text { with } \\
& \gamma_{i}=2(-1)^{i+1 /[(2 i-1) \pi],}
\end{aligned}
$$

The result with Eq. 22 allows the point estimate $\hat{\rho}$ to be used by itself to test the null hypothesis of a unit root. Another popular statistic for testing the null hypothesis that $\rho=1$ is based on the usual OLS $t$-test of this hypothesis,

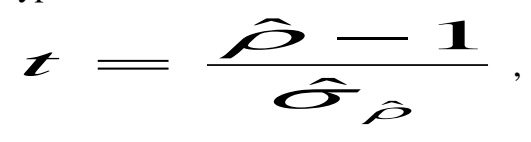

where $\hat{\sigma}_{\hat{\rho}}$ is the usual OLS standard error for the estimated coefficient,

$$
\hat{\sigma}_{\hat{p}}=s_{e}\left(\sum_{t=2}^{N} x_{t-1}^{2}\right)^{-1 / 2},
$$

and $s_{e}$ denotes the standard deviation of the OLS estimate of the residuals in the regression model with Eq. 20, estimated as

$$
s_{e}^{2}=\frac{1}{N-2} \sum_{t=2}^{N}\left(x_{t}-\hat{\rho} x_{t-1}\right)^{2} \text {. }
$$


Dickey and Fuller (1979) derived the limiting distribution of the statistic $t$ under the null hypothesis that $\rho=1$ as

$$
t \stackrel{D}{\longrightarrow} 2 \Gamma^{-1 / 2}\left(\Lambda^{2}-1\right) \text {. }
$$

The unit root test described above is valid if the time series $\left\{x_{t}\right\}$ is well characterized by an $\operatorname{AR}(1)$ with white noise errors. Many hydrological time series, however, have a more complicated dynamic structure than is captured by a simple $\mathrm{AR}(1)$ model. The basic autoregressive unit root test can be augmented (referred to as $\mathrm{ADF}$ test) to accommodate general $\operatorname{ARMA}(p, q)$ models with unknown orders (Said and Dickey, 1984; Hamilton, 1994, pp 516-530). The ADF test is based on estimating the test regression

$$
x_{t}=\beta D_{t}+\phi x_{t-1}+\sum_{j=1}^{p} \psi_{j} \nabla x_{t-j}+\varepsilon_{t}, t=1,2, \ldots, N
$$

Where;

$D_{t}$ is a vector of deterministic terms (constant, trend, etc.). The $p$ lagged difference terms, $\nabla x_{t-j}$, are used to approximate the ARMA structure of the errors, and the value of $p$ is set so that the error $\varepsilon_{t}$ is serially uncorrelated. Said and Dickey (1984) show that the Dickey-Fuller procedure, which was originally developed for autoregressive representations of known order, remains valid asymptotically for a general $\operatorname{ARIMA}(p, 1, q)$ process in which $p$ and $q$ are unknown orders.

\section{Impact of Rupee Dollar Exchange Rate EXCHANGE RATE}

Table -1 Reveals the empirical results from Augmented Dickey-Fuller test (ADF) for US Exchange Rate. The data is stationary when the calculated value is smaller than the critical value. The statistics value for ADF test is (-34.274999). The test produced significant result at $1 \%$ level $(-3.435711)$ when time trend was included. It is to be noted that the ADF test provides evidence that the series are stationary. The critical values include three significant level at $1 \%$ ( -3.435711$), 5 \%$ ($2.863789)$ and $10 \%(-2.567994)$. The series confirmed that it is stationary in the significant level $1 \%$ itself and therefore no further test was required.

Augmented Dickey-Fuller Unit Root Test on Exchange Rate

\begin{tabular}{|l|l|l|l|}
\hline & & t-Statistic & Prob.* \\
\hline Augmented Dickey-Fuller test statistic & & -34.274999 & 0.000000 \\
\hline Test critical values: & $1 \%$ level & -3.435711 & \\
\hline & $5 \%$ level & -2.863789 & \\
\hline & $10 \%$ level & -2.567994 & \\
\hline & & & \\
\hline
\end{tabular}

\section{S\&P CNX NIFTY JUNIOR}

Table-2 Reveals the empirical results from Augmented Dickey-Fuller test (ADF) for National Exchange Rate in S\&P CNX NIFTY JUNIOR. The data is stationary when the calculated value is smaller than the critical vale. The statistics value for ADF test is (0.814027). The test produced significant result at $1 \%$ level $(-3.435467)$ when time trend was included. It is to be noted that the ADF test provides evidence that the series are stationary. The critical values include three significant level at $1 \%(-3.435467), 5 \%(-2.863681)$ and $10 \%(-2.567936)$. The series confirmed that it is stationary in the significant level $1 \%$ itself and therefore no further test was required.

Augmented Dickey-Fuller Unit Root Test on S\&P CNX NIFTY JUNIOR

\begin{tabular}{|l|l|l|l|}
\hline & & t-Statistic & Prob. $^{*}$ \\
\hline Augmented Dickey-Fuller test statistic & & $\mathbf{- 0 . 8 1 5 1 9 6}$ & $\mathbf{0 . 8 1 4 0 2 7}$ \\
\hline Test critical values: & $1 \%$ level & $\mathbf{- 3 . 4 3 5 4 6 7}$ & \\
\hline & 5\% level & $\mathbf{- 2 . 8 6 3 6 8 1}$ & \\
\hline & $10 \%$ level & $\mathbf{- 2 . 5 6 7 9 3 6}$ & \\
\hline
\end{tabular}

\section{S\&P CNX NIFTY}

Table-3 gives the empirical data of ADF test from S\&P CNX NIFTY index. If the data is stationary, the calculated value is smaller than critical value. The statistics value for ADF test is (0.609122). When the time trend provided, the test produced a significant result at $1 \%$ level $(-3.435467)$. ADF test proves the series are stationary. The test critical values at $1 \%$ level is ($3.435467)$, is $5 \%$ level $(-2.863681)$ while at $10 \%$ level $(-2.567936)$. 
Augmented Dickey-Fuller Unit Root Test on S\&P CNX NIFTY

\begin{tabular}{|l|l|l|l|}
\hline & & t-Statistic & Prob.* \\
\hline Augmented Dickey-Fuller test statistic & & -1.347464 & 0.609122 \\
\hline Test critical values: & $\mathbf{1 \%}$ level & -3.435467 & \\
\hline & $\mathbf{5 \%}$ level & -2.863681 & \\
\hline & $\mathbf{1 0 \%}$ level & -2.567936 & \\
\hline
\end{tabular}

\section{S\&P CNX 500}

Table-4 Gives the empirical data of ADF test from S\&P CNX 500 index. If the data is stationary, the calculated value is smaller than critical value. The statistics value for ADF test is $(0.654285)$. When the time trend provided, the test produced a significant result at $1 \%$ level (-3.434581). ADF test proves the series are stationary. The test critical values at $1 \%$ level is $(-3.434581)$, is 5\% level (-2.863289) while at 10\% level (-2.567726).

Augmented Dickey-Fuller Unit Root Test on S\&P CNX 500

\begin{tabular}{|l|l|l|l|}
\hline & & t-Statistic & Prob. $^{*}$ \\
\hline Augmented Dickey-Fuller test statistic & & -1.250508 & $\mathbf{0 . 6 5 4 2 8 5}$ \\
\hline Test critical values: & $1 \%$ level & $\mathbf{- 3 . 4 3 4 5 8 1}$ & \\
\hline & $5 \%$ level & -2.863289 & \\
\hline & $10 \%$ level & -2.567726 & \\
\hline
\end{tabular}

\section{S\&P CNX IT}

Table-5 Reveals the empirical results from Augmented Dickey-Fuller test (ADF) for National Exchange Rate in S\&P CNX IT. The data is stationary when the calculated value is smaller than the critical value. The statistics value for ADF test is (0.949730). The test produced significant result at $1 \%$ level $(-3.435463)$ when time trend was included. It is to be noted that the ADF test provides evidence that the series are stationary. The critical values include three significant level at $1 \%$ ($3.435463), 5 \%(-2.863679)$ and $10 \%(-2.567935)$. The series confirmed that it is stationary in the significant level $1 \%$ itself and therefore no further test was required.

Augmented Dickey-Fuller Unit Root Test on S\&P CNX IT

\begin{tabular}{|l|l|l|l|}
\hline & & t-Statistic & Prob. $^{*}$ \\
\hline Augmented Dickey-Fuller test statistic & & $\mathbf{- 0 . 0 7 9 4 9 3}$ & $\mathbf{0 . 9 4 9 7 3 0}$ \\
\hline Test critical values: & $\mathbf{1 \%}$ level & $\mathbf{- 3 . 4 3 5 4 6 3}$ & \\
\hline & $\mathbf{5 \%}$ level & $\mathbf{- 2 . 8 6 3 6 7 9}$ & \\
\hline & $\mathbf{1 0 \% \text { level }}$ & $\mathbf{- 2 . 5 6 7 9 3 5}$ & \\
\hline
\end{tabular}

\section{S\&P CNX MIDCAP}

Table-6 Gives the empirical data of ADF test from S\&P CNX MIDCAP index. If the data is stationary, the calculated value is smaller than critical value. The statistics value for ADF test is $(0.763327)$. When the time trend provided, the test produced a significant result at $1 \%$ level $(-3.435463)$. ADF test proves the series are stationary. The test critical values at $1 \%$ level is ($2.863679)$, is $5 \%$ level (-2.868876) while at $10 \%$ level (-2.567935).

Augmented Dickey-Fuller Unit Root Test on S\&P CNX MIDCAP

\begin{tabular}{|l|l|l|l|}
\hline & & t-Statistic & Prob.* \\
\hline Augmented Dickey-Fuller test statistic & & $\mathbf{- 0 . 9 7 6 5 8 5}$ & $\mathbf{0 . 7 6 3 3 2 7}$ \\
\hline Test critical values: & $1 \%$ level & $\mathbf{- 3 . 4 3 5 4 6 3}$ & \\
\hline & $\mathbf{5 \%}$ level & $\mathbf{- 2 . 8 6 3 6 7 9}$ & \\
\hline & $10 \%$ level & $\mathbf{- 2 . 5 6 7 9 3 5}$ & \\
\hline
\end{tabular}

\section{S\&P CNX BANK}

Table-7 Given the empirical data of ADF test from S\&P CNX BANK index. If the data is stationary, the calculated value is smaller than critical value. The statistics value for ADF test is $(-1.456198)$. When the time trend provided, the test produced a significant result at $1 \%$ level $(-3.435450)$. ADF test proves the series are stationary. The test critical values at $1 \%$ level is $(-$ $3.435450)$, is $5 \%$ level $(-2.863673)$ while at $10 \%$ level $(-2.567932)$. 
Augmented Dickey-Fuller Unit Root Test on S\&P CNX Bank Indices

\begin{tabular}{|l|l|l|l|}
\hline & & t-Statistic & Prob. $^{*}$ \\
\hline Augmented Dickey-Fuller test statistic & & $-\mathbf{0 . 6 6 4 3 5 0}$ & $\mathbf{0 . 8 5 3 3 7 5}$ \\
\hline Test critical values: & $1 \%$ level & -3.435497 & \\
\hline & $5 \%$ level & -2.863694 & \\
\hline & $10 \%$ level & -2.567943 & \\
\hline
\end{tabular}

\section{S\&P CNX 100}

Table-8 Reveals the empirical results from Augmented Dickey-Fuller test (ADF) for National Stock Exchange. The data is stationary when the calculated value is smaller than the critical value. The statistics value for ADF test is (0.653769). The test produced significant result at $1 \%$ level $(-0.653769)$ when time trend was included. It is to be noted that the ADF test provides evidence that the series are stationary. The critical values include three significant level at $1 \%(-3.435467), 5 \%(-2.863681)$ and $10 \%(-2.567936)$. The series confirmed that it is stationary in the significant level $1 \%$ itself and therefore no further test was required.

Augmented Dickey-Fuller Unit Root Test on S\&P CNX 100

\begin{tabular}{|l|l|l|l|}
\hline & & t-Statistic & Prob.* \\
\hline Augmented Dickey-Fuller test statistic & & -1.251512 & 0.653769 \\
\hline Test critical values: & $1 \%$ level & -3.435467 & \\
\hline & $5 \%$ level & -2.863681 & \\
\hline & $10 \%$ level & -2.567936 & \\
\hline
\end{tabular}

\section{S\&P CNX INFRASTRUCTURE}

Table-9 Given the empirical data of ADF test from S\&P CNX Infrastructure index. If the data is stationary, the calculated value is smaller than critical value. The statistics value for ADF test is (0.255217). When the time trend provided, the test produced a significant result at $1 \%$ level (-3.435467). ADF test proves the series are stationary. The test critical values at $1 \%$ level is $(-3.435467)$, is $5 \%$ level $(-2.863681)$ while at $10 \%$ level $(-2.567936)$.

Augmented Dickey-Fuller Unit Root Test on S\&P CNX Infrastructure

\begin{tabular}{|l|l|l|l|}
\hline & & t-Statistic & Prob.* \\
\hline Augmented Dickey-Fuller test statistic & & -2.074573 & 0.255217 \\
\hline Test critical values: & $1 \%$ level & -3.435467 & \\
\hline & $5 \%$ level & -2.863681 & \\
\hline & $10 \%$ level & -2.567936 & \\
\hline
\end{tabular}

\section{S\&P CNX 500}

Table -10 Gives the empirical data of ADF test from S\&P CNX 500 index. If the data is stationary, the calculated value is smaller than critical value. The statistics value for ADF test is $(0.380229)$. When the time trend provided, the test produced a significant result at $1 \%$ level (-3.435492). ADF test proves the series are stationary. The test critical values at $1 \%$ level is ($3.435492)$, is $5 \%$ level (-2.863692) while at $10 \%$ level (-2.567942).

Augmented Dickey-Fuller Unit Root Test on S\&P CNX 500

\begin{tabular}{|l|l|l|l|}
\hline & & t-Statistic & Prob.* \\
\hline Augmented Dickey-Fuller test statistic & & -1.801166 & 0.380229 \\
\hline Test critical values: & $1 \%$ level & -3.435492 & \\
\hline & $5 \%$ level & -2.863692 & \\
\hline & $10 \%$ level & -2.567942 & \\
\hline
\end{tabular}

\section{FINDINGS}

$\checkmark \quad$ Augmented-Dickey Fuller (ADF) Test for all the 9 indices and Exchange rate showed stationary at First difference and which was significant at $1 \%$, $5 \%$ and $10 \%$ levels. $\checkmark \quad$ The actual values and predicted values were more or less the same during the study period for both indices. 


\section{SUGGESTIONS}

On the basis of the findings of the study, important suggestions are provided to the Investors and to the Regulators.

$\checkmark$ Whenever the market predicted the price movements exactly, it would minimize the risk. Hence it would be beneficial to the investors, hedgers and brokers.

$\checkmark$ The Impact in the stock market provides accurate price prediction. Hence the investors could invest for short term profitability.

$\checkmark$ Regulators should introduce new regulation for forecasting for the benefit of investors, brokers and financial market participants.

$\checkmark$ There was no uniformity in the returns for all the years and there were high negative returns and high positive returns during some months. Therefore, the Market Regulators should take appropriate steps to reduce this gap. .

$\checkmark$ Before investing in any securities, the investor can make a risk analysis then invest the stock market.

\section{CONCLUSION}

This study investigated the volatility of US dollar exchange rate and the stock market. It is also analysis the impact of exchange rate on the indices namely S\&P CNX NIFTY, S\&P CNX NIFTY JUNIOR, S\&P CNX IT, S\&P CNX BANK, S\&P CNX 100, S\&P CNX DEFTY, S\&P CNX 500, S\&P CNX MIDCAP, S\&P CNX INFRASTURARE, index. Regarding returns, even though there is evidence that index return decrease in response to changes in Exchange rate. The study proves statistically that there is a significant Impact in US Exchange rate and National Stock Exchange measured by different models. The predictive ability of ADF model used with more modification in the variance equation truly captures the trend of Impact. In addition, base US Exchange rate is exposed more often to exogenous variable which disturb Impact levels more than stock index. ADF model analysis reveals the Impact of Exchange rare and Stock indices.

\section{REFERENCES}

[1] Anthony G. Puxty, J. Colin Dodds, Richard M. S. Wilson, (1988), "Financial management: method and meaning", Pg.No.536

[2] Arthur I. Stonehill, Michael H. Moffett, (1996), “International Financial Management", Pg.No.256.

[3] Apte, (2006), "International Financial Management", Pg.No.655

[4] Alan C. Shapiro, (2008), "Multinational Financial Management", $8^{\text {th }}$ Edition, Pg.No. 772
[5] Cheol S. Eun, Bruce G. Resnick, (2007), "International financial management", Pg.No.536

[6] Charles N. Henning, William Pigott, Robert Haney Scott, (1978), "International financial management", Pg.No.576

[7] Carlos Correia, David Flynn, Enrico Uliana, (2007), "Financial Management", Pg.No.1120

[8] Cirvante. R., (1956), "The Indian capital market", Pg.No.226

[9] Donald D. Bergh, David J. Ketchen, (2009), "Research Methodology in Strategy and Management", Volume 5, Pg.No.318

[10] Donald R. Lessard, (1985), "International financial management: theory and application", Pg.No.594

[11] Adler.M\&Dumas.B (1984), "Exposure to Currency Risk: Definition and Measurement", Financial Management 13, pp. $41-50$.

[12] Aggarwal.R, Inclan.C and Leal.R (1999), "Volatality in Emerging Markets", Journal of Financial and Quantitative Analysis 34, pp. 33 -55.

[13]BernaOkan, OnurOlgun and SefaTakmaz(2009), "Volume and Volatility: A Case of ISE-30 Index Future",International Research Journal of Finance and Economics.

[14] Ching-chunwel(2009), "an empirical analysis of the Taiwan institutional trading volume volatility spillover on stock market index return",Economics Bulletin, www.ssrn.org

[15] Bollerselv.T (1986), "GeneralisedAutorregressive Conditional Heteroskedasticity", Journal of Econometrics, 31, 307 - 327.

[16] Engle R F (1982), "Autorregressive Conditional Heteroskedasticity with Estimates of the Variance of United Kingdom Inflation", Econometrica 50, pp. 987 - 994.

[17] ErdemCumhur, Arslan C.K and Erdem M.S (2005), "Effects of MacroeconomicVariables on Istanbul Stock Exchange Indices", Applied Financial Economices 15, pp. 987 - 994.

[18]Fama E.F (1981), "Stock Returns, Real Activity, Inflation and Money", American Economic Review 71 , pp. $545-565$.

[19] HalilKiymaz and Eric Girard, (2009)“Stock Market Volatility and Trading Volume: An Emerging Market Experience"Icfai university

[20] Korniek, Anton (2010), "Capital Flows: busting the Boom”, Emerging Market, November 12, 2010.

[21] MalabikaDeo ,K.srivivasan,K.devanadhen (2008), "the empirical relationship between stock return,trade volume and volatility :evidence from select asian-pacific stock market,"European journal of finance and administrative science, www.eurujournal.com 
[22] Mohammad IqbalTahir (2006), "stock market volatility : evidence from Sweden,"www.dostoc.com

[23] Nidal Rashid sabri, "the impact of trading volume on stock price volatility in the arab economy," birzeit university

[24] OtavioRibeiro De Medeiros and BernardusFerdinandusNazar Van Doornik(2008), "The empirical relationship between stock returns, return volatility and trading volume in the Brazilian stock market," Brazilian Business Review.

[25] Pradeepmavuluri, nagarjuna.B, "revisiting volume and volatility relationship, evidence from India,www.ssrn.org

[26] Punithavathavathypandian (2009), "stock market volatility in Indian stock exchange”, indiastat.com

[27] Pettis, Michal (2010), "Global Rebalancing: What the end game will look like”, Emerging Market, November 12, 2010.

[28] Rajwade, AV (2010), "Capital Flows, Exchange Rate and Balance of Payments Crises", Monthly Economic digit, MEDC, November 2010.

[29] Renters (2010), "Stiglitz urges Capital Controls to Curb hot money", Reuters, Hong Kong, November 10, 2010.

[30] Saravanan G and malabikadeo, (2000), "new insights into impact of volatility of future trading on the underlying spot market volatility,"www.ssrn.org 